\title{
Neo-Functionalism as a Theory of Disintegration
}

\author{
Philippe C. Schmitter ${ }^{1} \cdot$ Zoe Lefkofridi $^{2,3}$
}

Received: 2 November 2015/ Accepted: 22 December 2015/Published online: 3 March 2016

(C) The Author(s) 2016. This article is published with open access at Springerlink.com

\begin{abstract}
In this article, we exploit neo-functionalism as a conceptual and theoretical instrument that helps understand the current crisis and its future consequences. We formulate a series of suppositions and hypotheses, which we evaluate using existing data sources and related research. Our empirical analysis produces a mixed picture: though reality seems to conform with some neo-functionalist expectations, it contradicts some others. The latter disproven results, however, also suggest that there might be some corresponding increase in the likelihood that the EU could disintegrate.
\end{abstract}

Keywords European integration · Disintegration $\cdot$ Neo-functionalism $\cdot$ Crisis

\section{Neo-functionalism and Disintegration ${ }^{1}$}

The European Union (EU)'s future has been put into question in practice as well as in theory (Lefkofridi and Schmitter 2015; Schmitter 2012; Vollard 2008). In a purely probabilistic sense, the fact that the EU shows signs of disintegration is

\footnotetext{
1 A previous version of this paper was presented at the panel "European Disintegration-A Blind Spot of Integration Theory?", 22nd Council of European Studies (CES) Conference, Paris July 8-10, 2015. We are grateful to Lena Ramstetter for research assistance.
}

$\triangle$ Zoe Lefkofridi

Zoe.Lefkofridi@sbg.ac.at; Zoe.Lefkofridi@eui.eu

Philippe C. Schmitter

Philippe.Schmitter@eui.eu

1 Department of Social and Political Sciences, European University Institute, Fiesole, Italy

2 Faculty of Sociology and Political Science, University of Salzburg, Salzburg, Austria

3 Robert Schuman Center for Advanced Studies, European University Institute, Fiesole, Italy 
hardly surprising since most of the many efforts at trans-national regional integration since the Second World War have exhibited similar symptoms. Either they failed to fulfil their initial commitments, withdrew from tasks already assigned to them or simply collapsed altogether. That so many observers of the EU regarded it as exceptional and, hence, immune to disintegration perhaps explains the apparent surprise among observers. Of course, so far all that has been observed are "morbidity symptoms", not some definitive diminution or demise.

Nevertheless, the events and processes triggered by the dual crises of the Euro and the EU do require some re-thinking about the theories (and their presumptions) that have been used to explain the heretofore relative success of regional integration in Europe (for a critical discussion, see Vollard 2008). Prominent among these has been the neo-functionalist approach. The temptation, therefore, would seem to be to call into question its basic assumption, namely, the predominant role played by a diversity of self-interested actors competing with each other for the functional distribution of public goods provided by regional institutions. This could then be replaced by another approach, probably, some version of inter-governmentalism in which the only relevant actors are states promoting their self-regarding national interests and protecting their citizens from foreign intromission into their affairs and values. ${ }^{2}$ In this article, it is our purpose not to reject but to exploit neo-functionalism as a conceptual and theoretical instrument that helps understand the current crisis and its future consequences. It does not deny that the formal institutions and informal practices of the EU are threatened or that previously unobserved tendencies have emerged-but seeks to interpret them in ways that are consistent with the theory's basic assumptions.

As an approach to understanding trans-national regional integration, neofunctionalism has been frequently criticized for its alleged bias in favor such a process-despite explicit protestations to the contrary by one of its practitioners (Schmitter 2004). The confusion seems due to the fact that the conditions present in Western Europe were unusually favorable to the generation/cultivation of spill-overs from one functional arena to another and from lower to higher levels of common authority. When the approach was applied elsewhere to efforts at regional integration in less favorable settings, it (correctly) predicted failure even to meet the objectives proclaimed in their founding treaties (Schmitter 1970; Haas and Schmitter 1964).

The normal expectation with regard to the performance of such regional or global efforts at functional cooperation/integration is that they should "self-encapsulate", i.e., at best, they should perform the initial tasks bestowed upon them by member states by international agreement and then persist as stable institutionalized components of the interstate order. Only in exceptional circumstances or conditions should actors within such arrangements be expected to agree to a redefinition of their functional tasks or an upgrading of their authoritative status.

Given the current and concurrent crises of the EU and the Euro, it would seem appropriate to explore the hypotheses and presumptions that neo-functionalism might employ to predict "spill-backs" rather than "spill-overs". A spill-back is

\footnotetext{
${ }^{2}$ For an extreme version based on the argument that this has always and only been the purpose of regional integration in Europe, see Milward (1992).
} 
when member states no longer wish to deal with a policy at the supranational level, e.g., the collapse of the Euro or Member States (MSs)' exits from the Eurozone or even the EU-be they coerced (e.g., Grexit) or voluntary (e.g., Brexit). Such "spillbacks" are fervently advocated by parties on the radical left and right (albeit for different reasons) in both debtor and creditor states (e.g., Freiheitliche Partei Österreichs, French Front National, Communist Party of Greece). In this piece, we apply neo-functionalist theory in an effort to understand the causal logic of disintegration, and its likely point of departure.

When and why should one expect that a given set of institutions of regional integration would agree (or be forced) to withdraw their competence to make policy in an arena previously subject to its trans-national "governance"? Or, more dramatically, under what condition might it collapse altogether? The EU is not likely to break as long as it successfully fulfills key functions for the Union's economy and society as a whole; but it can and will break if it does not. Against this background, we first articulate explicit (and implicit) neo-functionalist suppositions and hypotheses. Next, we try to identify whether and to what extent disintegration is indeed a possibility in the empirical world. To this aim, we examine different pieces of empirical evidence in favor or against neo-functionalist expectations; we employ official databases (e.g., Eurostat, Eurobarometer), rely on existing analyses but also discuss the most recent developments, namely Grexit and the accommodation of war refugees, when politicization and conflict reached their zenith.

\section{Neo-functionalist Suppositions and Hypotheses}

As is the case with any theory, neo-functionalism (NF) has suppositions that are explicit (some of which may be exclusive to it) and others that are implicit (and usually shared with other theories). These, in turn, produce hypotheses that can be tested against empirical data-quantitative or qualitative. All the explicit ones are ultimately derived from the core assumption of NF, namely, that the process of regional integration (in the contemporary setting) depends on the realization of mutual gains from cooperation in policy arenas characterized by high levels of functional interdependence.

\section{Explicit (and sometimes exclusive) Suppositions and Hypotheses \\ 1. Economic Integration and Interdependence}

The removal of barriers to trade, investment and human mobility (negative integration) and the creation of common, market-regulating rules (positive integration) will produce a continuous increase in the interdependence of MSs. This increase will not only be absolute and general for the trans-national regional organization (TRO) as a whole, but it will also be the case for all of its MSs. The distribution of this increase will not accrue primarily to a single Member State (MS) or a set of 'hegemonic' MSs within the TRO. The increase will be distinctively regional, i.e., greater among MSs than between them and non-MSs. 


\section{Benefits and Public Perceptions}

The net benefits from this increase in regional interdependence will be positive, both for the economy as a whole and for the population at large. These benefits will be recognized and appreciated by those affected, and they will be (more-or-less) evenly distributed and shared across MSs. Therefore, mass publics will tend to support positively the existing TRO and expansions of its compétences in the future. This support may take the form of passive consent or active assent, depending on the visibility of threats and the magnitude of benefits.

\section{Security}

The primary expected benefit from regional integration should be greater security, both against predation by outsiders and in favor of material benefits from insiders. In the course of the integration process, actors may shift their perception of expected benefits, especially after some of them have been satisfied. But this will not involve a major shift toward the satisfaction or provision of non-material benefits such as the protection of national identity, the fulfillment of traditional values or the desire for a sense of affective belonging - at least, not until the integration process is sufficiently advanced to have produced a stable political equilibrium.

\section{Role of Experts}

Neo-functionalism assigns a major role to experts, both those in the TRO and those in the respective national bureaucracies. They are presumed to be anxious to expand their role in policy-making and, therefore, to introduce new initiatives when the opportunity arises (usually as a result of crisis, see below Supposition I.8). They are also supposed to be wary of "premature" politicization and, therefore, to internalize emerging conflicts and resolve them without including outsiders, especially those with a wider political agenda. Experts are presumed to form something approximating an "epistemic community" based on a high level of agreement concerning the nature of the problem and the means for resolving it. Moreover, this shared scientific paradigm is also supposed to be predisposed to favor an increase in intervention by public authority, in this case, by the TRO.

\section{Respect for EU Decisions}

The policies of the TRO should be largely self-enforcing, given the presumption of net benefits. MSs will respect their commitments to implementing the policies of the TRO (pacta sunt servanda) and do so voluntarily and effectively, even when they have not approved the decisions taken. The TRO will not be obliged to acquire a monopoly on the use of legitimate violence within its territory (i.e., to become a state) in order to ensure compliance because this property can be reliably left to its MSs. The TRO will, however, have to rely increasingly on its capacity for adjudicating disputes ("legal integration") about the distribution of benefits, but 
especially concerning the honest and reliable implementation of its decisions by MSs.

\section{Convergence}

Increased interdependence of MSs, plus the shared and (more or less) equal distribution of benefits, will lead to a convergence among MSs in economic performance and social protection. Under most favorable conditions, this will mean an "upward" convergence in which the initially less well-endowed and performing MSs will come closer to attaining the levels of performance of the better endowed and better performing ones. In the absence of such a convergence, the TRO should be prepared to compensate the relative losers via some mixture of greater leniency (negative integration) or material redistribution (positive integration).

\section{Incremental Positive and Negative Integration}

The process of regional integration will be incremental, involving a sequence of interrelated decisions. The process does not include major "threshold effects" or decisions that are so much more consequential or controversial that they require a radically different mode of decision-making or conflict resolution. This incremental continuity will not be interrupted when (and if) the TRO switches from cooperation among MSs to cooperation of MSs in their relations with outside, non-member states. Nor will this relative continuity be significantly affected when the TRO is compelled to shift its attention from initially easier issues to resolve to more difficult ones whose rewards are less visible and delayed in effect. Nor will it be significantly affected when it shifts from the task of removing barriers to exchange (negative integration) to the task of regulating these exchanges and compensating for their potential perverse effects (positive integration).

\section{Conflict and Politicization}

The process of regional integration inevitably generates conflict among MSs, especially given the novelty of the effort and, hence, the impossibility of calculating accurately all the potential consequences of collective decisions. The most significant sources of conflict among MSs and between their constituent interests are endogenous, i.e., produced by the integration process itself, and these are easier to resolve "in house". The usual process for resolving these conflicts is to reach a compromise involving some mixture of increased authority for regional institutions ("build-up") or an extension of their policy scope ("spill-around") or both ("spillovers"). To the extent this prevails, the result will be an expansion of the role of those TRO institutions most capable of exercising supranational authority in relative independence from the authority and sovereignty of MSs. The emergence of greater conflict with regard to the TRO, its policies and its increased autonomy will unavoidably result in "politicization", i.e., the mobilization of wider and wider publics paying attention to the integration process and expressing a greater diversity of opinions about it. According to Supposition I.2, this mobilization on balance 
should be favorable based on the net distribution of benefits to the economy and population.

\section{Implicit (and not unique) Suppositions and Hypotheses \\ 1. Democracy}

The member states of the TRO must have regimes that are both democratic and liberal. They have regular and reliable mechanisms for holding their rulers accountable to citizens and they are committed to respecting the rule of law, human rights and tolerant of their citizens engaging in political activities. ${ }^{3}$ The type of democracy need not be the same and may even become less so over time, but citizens must be free to form various types of collective political organizationsparties, associations and movements - and to do so across national borders. The regimes of MSs allow their citizens to both support and criticize the policies of the TRO. The political institutions of MSs provide regular and predictable access to representatives of national and international interests, passions and convictions. The governments of MSs do not systematically discriminate in providing information to their citizens-and allow TRO authorities to directly address these citizens. Needless to say, these conditions are not only present at the time of becoming a member, but persist throughout the country's membership.

\section{Consequences of Enlargement}

The enlargement of the TRO to incorporate more members does not fundamentally alter the previously established processes or institutions of regional integration. Even if it is highly likely that the new entrants will have different economic and social endowments at the time of entry, existing TRO formal institutions and informal practices will be able to adjust to them. The sheer number of accession states may also make the decision-making process slower and more difficult-and the more that enter at the same time, the greater the impact will be-but it will not result in stalemate, provided that negotiations persist and compromises can be reached.

\section{Pluralistic Conflicts}

The pattern of conflicts mentioned above in Supposition I.7 will be pluralistic, i.e., it will not result in the formation of a distinctive subset of MSs that are regular and systematic losers across a range of issues. Such a polarization of conflicting actors-whether at the national or sub-national level-can be avoided if the distribution of benefits from integration is both proportional and convergent. It can also be avoided it the underlying pattern of social and economic cleavages is crosscutting, e.g., some small states are rich and others are poor; some centrally located

\footnotetext{
3 Both of these became formal obligations for membership in the EU, but were not at the time NF was developed as a theory. It was simply presumed as a constant in the case of Europe, but it was a variable in such cases as South American and Central American integration in the 1970s and 1980s.
} 
states have more and others less state capacity; some historically dominant powers are willing and others less willing to accept a sub-ordinate position.

\section{La Finalité?}

All theories of regional integration-explicitly or implicitly—presume that it will eventually end in an enduring and stable set of institutions. NF has been notoriously reluctant to predict what this "la finalité politique" might be (not to mention when it might come about), but it does presume that the TRO will evolve institutionally as a function of the benefits it distributes and conflicts it resolves. As we have seen in Supposition I.5, NF seemed to presume that it would not be necessary for the TRO (or the EU in this case) to fulfill all of the requisites historically associated with the emergence of a sovereign national state. But what was not imagined was that, instead of forming a distinct hierarchy of institutions concentrated in a single location (Brussels) according to the model set by most previous patterns of national political integration, the EU resulted in a very dispersed set of institutions at different locations with different internal structures and even with different memberships. When the crisis of Euro hit, the EU possessed no coherent and reendowed set of institutions to deal with it. The result was a chaotic, competitive and redundant effort to respond to this "mother of all crises" that might otherwise have produced a definitive breakthrough in the path to political integration.

\section{Exogenous Shocks}

Any TRO is inserted in a wider variety of international contexts and subject to unforeseen external events. These exogenous shocks and pressures are likely to have a differential impact upon MSs and to be a source of internal conflict, quite independent of the usual presumed endogenous ones. Their timing is also more unpredictable and unlikely to be coordinated with the status or cyclical properties of endogenous conflicts. Moreover, they may be more difficult to resolve since the TRO is less likely to have the installed capacity to do so. And it is highly likely that in doing so, the MSs and their regional institutions will have to rely on the cooperation of non-MSs. Especially threatening to NF is the possibility that in response to such changes in the broader international context, actors within the TRO will find themselves having to deal with the "high" politics of national identity and security-for which they have no mandate or experience.

\section{Fairness}

Finally, the entire process of regional integration should be perceived by a substantial proportion of its beneficiaries/victims as "fair". Some of this will be ensured by the Suppositions discussed in I.2. with regard to the evenly shared distribution of benefits and actor perception of this, but fairness is a more elusive property in political relations, especially among states and populations that have had previous histories of unfair treatment by each other. The criteria for judging fairness 
(or justice) are highly subjective, but it is a definite advantage for any given TRO if these criteria are relatively similar-or at least commensurate-across MSs.

If any one of these Suppositions and Hypotheses is proven wrong when applied to the EU, then there are grounds for questioning the validity of that aspect of NFunless, of course, this unexpected variation can be "explained away" by mitigating factors. These disproven results also suggest that there might be some corresponding increase in the likelihood that the EU could disintegrate. If substantial chunks of them are not confirmed, that likelihood should increase exponentially. Needless to say, if all of them are falsified, neo-functionalism should be abandoned in favor of some other theory of regional integration (or the effort at theorizing should be abandoned altogether on the grounds that the EU experience is so sui generis that no theory can be based on it).

\section{Empirical Evidence: Towards Disintegration?}

In this section, we review empirical evidence that could (dis)confirm the above outlined Suppositions and Hypotheses. Due to lack of space, we limit ourselves to the exploration of the explicit ones ${ }^{4}$; to this aim, we rely on a variety of indicators and data sources, which we summarize in Table 1. Two caveats: first, the data we use for exploring these Suppositions and Hypotheses refer to a variable universe of MSs because the union has grown larger with successive enlargements. Second, because we are exploring many expectations simultaneously, we focus on national and EU averages, rather than going into detail, e.g., how specific socioeconomic groups benefit from and/or perceive integration. We structure the empirical discussion as follows: first, we examine degrees of interdependence; second we assess the resulting benefits and how these are perceived by the public; third, we discuss the role played by experts in this regard; fourth, we review evidence regarding the incremental character of integration and the respect for EU decisions and finally, we discuss conflict and politicization-which were intensified with the economic (2009-) and refugee crises (2015-).

\section{Interdependence and Hegemony? The Case of Trade}

To explore Supposition I.1 we begin by looking at trends in trade, which was the primary initial objective of economic integration and can help us assess the degree of interdependence among EU MSs. To recall, NF assumes an increase in interdependence for all Union members equally, and for all members of the Union compared to third countries. The situations where extra-EU trade is more important than intra-EU trade, or when one or a few members become "hegemons" contradict our Hypotheses and may also be signaling a higher likelihood of disintegration.

\footnotetext{
4 Though the empirics we discuss here do give hints regarding some of the implicit hypotheses, we hope that future research will engage in evaluating these hypotheses in detail.
} 
Table 1 Explicit Suppositions and Hypotheses-Indicators and Data Sources

1. Interdependence of MSs.

Indicators: Intra-EU Trade and Extra-EU Trade in the EU28 in 2013; Trends in individual MSs' imports and exports (2000-2010).

Sources Eurostat/Knoema; O' Neill and Terzi (2014); Sadeh (2014)

2. Benefits for the Economy as a whole and for the Society at large.

Indicators: Public attitudes to disintegration of the Union (i.e. how would you feel what if the EU had been scrapped?) (1973-2004); Personal Meanings of the EU (1997 and 2001);

Perceived benefits of own country's EU Membership (2007 and 2011); Okun's Misery Index; Unemployment rates.

Sources Eurobarometer; Lechmann (2009); Eurostat/Knoema

3. Security and Sense of Belonging (Identity)

Indicators: Public Opinion regarding appropriate level of government for Security and Defence in 2000 and in 2010; Evolution of prospective perception of (Exclusively National) Identity (1989-1995).

Sources Eurobarometer

\section{Role of Experts}

Indicators: Composition of expert groups that consult the European Commission; role of epistemic communities in the crisis and their conflicts

Sources Chwieroth (2007); Gornitzka and Sverdrup (2011); Rosenhek (2013)

5. Respect for EU Decisions

Indicators: Total number of cases before the ECJ (1970-2010); New actions for failure of a MS to fulfil its obligations (1952-2010).

Sources Court of Justice (2010).

6. Economic Convergence

Indicators: Growth rates

Sources Balcerowicz et al. (2013)

7. Incremental Positive and Negative Integration

Indicators: Amount of EU legislation; Activity of the Court

Sources Miller (2010); Court of Justice (2010)

8. Conflict and Politicization

Indicators: Anti-EU party success, social movements

Sources Accornero and Pinto (2015), Brack (2015), Della Porta (2012); Beichelt et al. (2014)

Surprisingly, empirical research on the relationship between economic integration and trade begun only in the 2000s. The few studies on the topic suggest a positive relationship between integration and trade: as economic integration deepened within the EC/EU, so did the reciprocal trade among EU members (Agur et al. 2007; Rose 2000, 2001, 2004). While the data show a slow, but steady rise of intra-EU trade, they also manifest that EU members become more and more open to trade in general, including an increase of external trade (e.g., Agur et al. 2007). Although intra-EU trade has been traditionally higher than extra-EU trade, there is variation across MSs also, Eurostat has observed a change in recent years: intra-EU 
trade is decreasing. ${ }^{5}$ Figure 1 shows the difference between EU internal and external trade for the $28 \mathrm{MSs}$ in 2013. Overall, for the EU28, intra-EU trade is much higher than extra-EU trade, though there is variation among MSs. Three EU MSs, Greece, Malta and the UK engaged more in external than in internal trade in 2013.

In a recent paper, O'Neill and Terzi (2014) analyze changes in world GDP and trade and extrapolate what the world trade situation will look like by 2020 if the current trend continues. According to their study, by 2020 the three key EU economies Germany, France and Italy will be focusing their trade relationships with countries outside the Euro area (China; developing/emerging markets) more than within it. Their analysis also suggests that the Euro may not have the expected beneficial effects on trade (O'Neill and Terzi 2014).

At the same time, recent research that focuses specifically on the effect of the common currency on trade shows that it has benefited intra-EU trade (Sadeh 2014). Sadeh (2014)'s analysis of the Euro's impact by type of MS in the period 1999-2006 also produces the interesting finding that trade increased more among peripheral states of the Eurozone (Greece, Italy, Ireland, Portugal and Spain) than among its core member states (Austria, Belgium, Finland, France, Germany and the Netherlands). During the same period, an increase in trade was observed between the periphery and the core of the Eurozone, albeit lesser than that observed among the peripheral states. This study thus concludes that at the micro-economic level the Euro works despite its macro-economic difficulties, and also suggests that, in the long run, the Euro is especially helpful to peripheral countries.

When we look at trends of individual MSs in imports and exports of goods within and outside the EU, we find great variation, and there is a single MS that performs much better than all others. Figure 2 shows longitudinal trends in imports from within (left graph) and outside (right graph) the EU. Based on the graph on the left, which concerns imports from within the EU, we can see that only a few countries stand out. Germany is the leading importer inside the EU (top line), followed by France, the UK, Italy, Belgium, the Netherlands, and Spain; all other countries crowd at the bottom, with Austria and Sweden leading this group. The graph on the right shows imports from outside the EU: here again Germany represents the top line on the graph, followed by the UK, the Netherlands, Italy, France, Spain, Belgium, Austria and Sweden; all the other countries are located at the very bottom.

Figure 3 demonstrates the trends in exports within the EU (left graph) and outside it (right graph). Regarding exports within the EU, a few among the many EU members stand out. Germany once again has the lead, although in this case its 'distance' from other MSs is much larger than in the case of imports. Germany is followed by the Netherlands, France, Belgium, Italy, UK; Spain leads the laggard group, followed by Austria, Sweden, Ireland and Portugal. When it comes to exports beyond the EU market (right graph), Germany has by far the best performance, followed by France, the UK, Italy; among the countries in the bottom of the graph the best performers are the Netherlands, Belgium, Spain, Sweden and Ireland.

\footnotetext{
5 More detailed information is to be found in Eurostat's online publication, URL:http://ec.europa.eu/ eurostat/statistics-explained/index.php/Intra-EU_trade_in_goods_recent_trends. Accessed 30 June 2015.
} 


\section{Eurostat.}

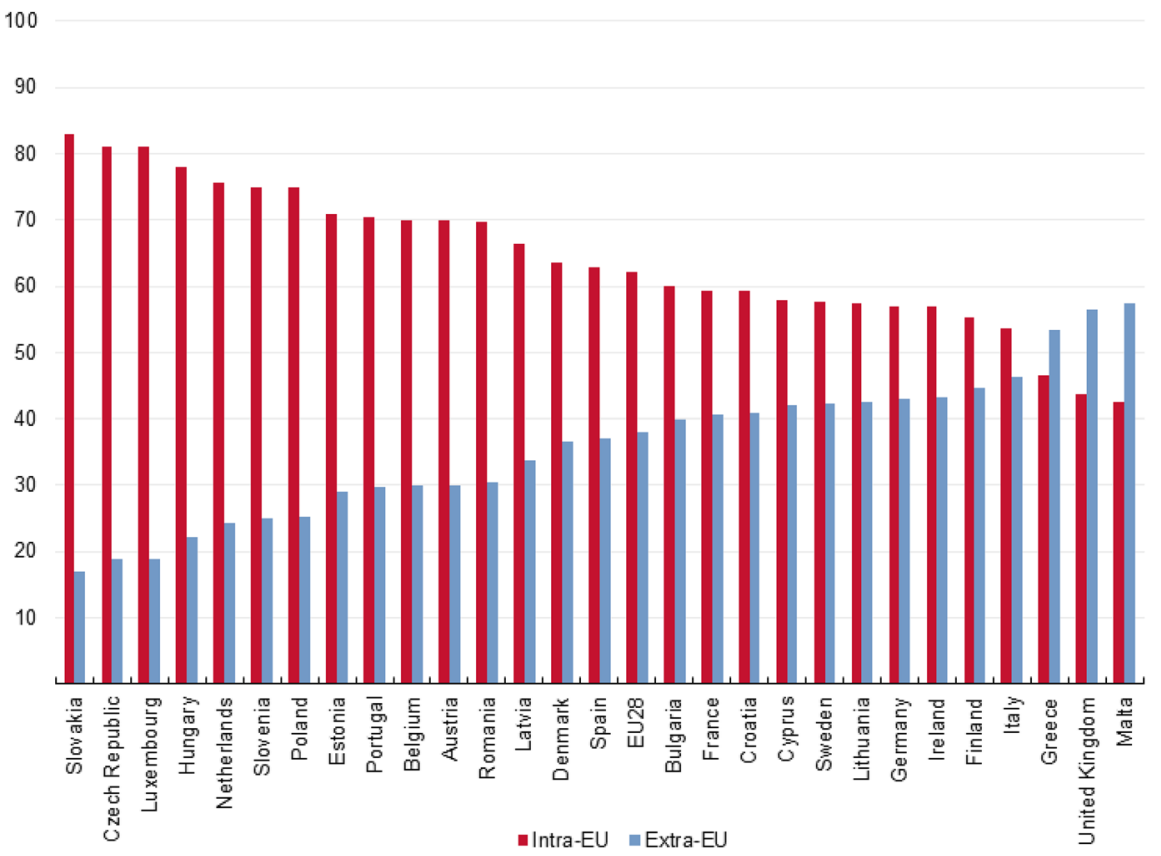

Fig. 1 Intra-EU and extra-EU trade in the EU28 in 2013. Source: Eurostat
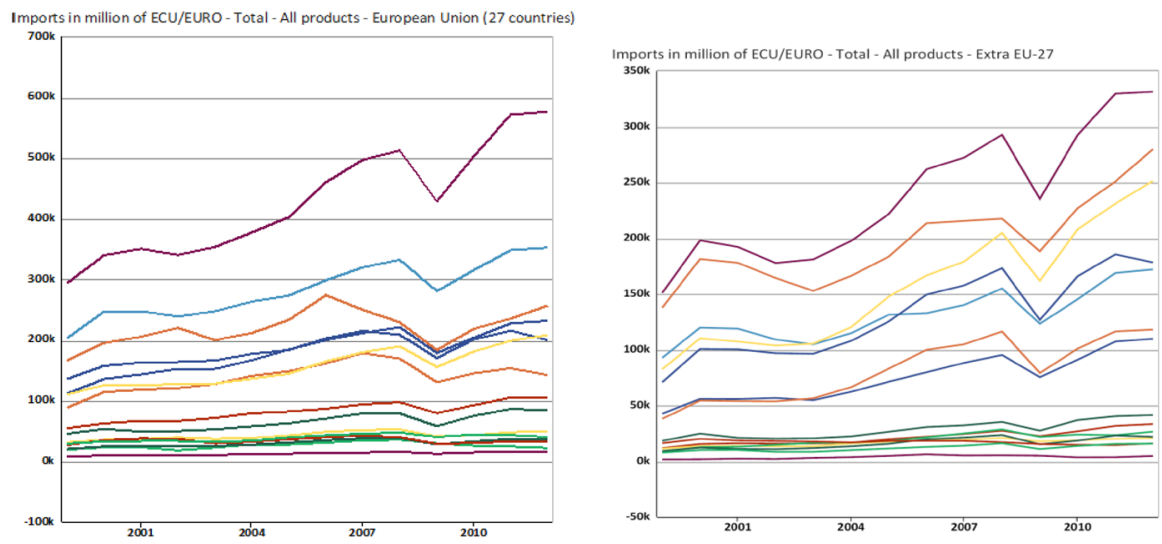

Fig. 2 Trends in imports from within (left) and outside (right) the EU27 (2000-2013). Source: Eurostat/ Knoema

To summarize, economic integration seems to have benefited trade among MSs of the EU. At the same time, there are clear indications of German hegemony, which consistently outperforms all other MSs (always top) across indicators. When comparing internal to external trade in the case of the EU's best performer, it seems 

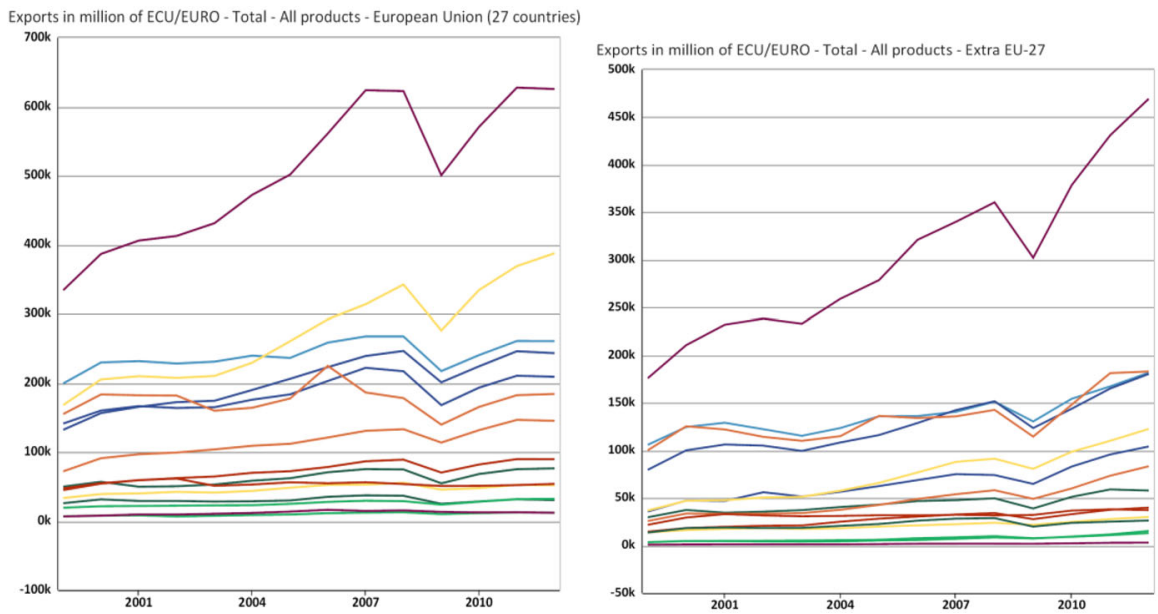

Fig. 3 Trends in exports within (left) and outside (right) the EU27 (2000-2013). Source: Eurostat/ Knoema

that, to date, internal EU trade has brought more gains than external trade: in 2012 Germany exported more products to other EU MSs than to countries outside the Union (Fig. 3, left and right graphs). That said, we observe a pronounced rise of Germany's exports outside the EU since the crisis, which may suggest that the EU's market hegemon is becoming more outward-rather than inward looking in its search for trading partners.

\section{Benefits for the Economy and Society}

The benefits of interdependence for the economy and society are assumed to be positive and recognized by the public. To examine Suppositions I.2, I.3 and I.6, we combine related data on public opinion with data on citizens' economic discomfort in each MS and trends in MSs' economic growth. We examine public attitudes towards disintegration, the benefits of EU membership, the EU's positive and negative connotations, the appropriate level of government for security and defense, and the evolution of national identity over time. Besides the aforementioned 'subjective' evaluations of the benefits of integration, we review data on economic discomfort, which constitute 'objective' evaluations of the benefits for society, as well as data on growth, which constitute indicators for the benefit experienced by a MS' economy as a whole.

\section{a. Public Perceptions of European Integration}

How do general public perceive integration? How much one appreciates something is reflected to how much s/he would care about losing it. Fortunately, the Eurobarometer used to contain a question that allows us to measure attitudes of EU citizens to disintegration of the Union. More specifically, EU citizens were asked: "If you were told tomorrow that the European Community (Common Market)- 
European Union-had been scrapped, would you be very sorry about it, indifferent or very relieved?". Unfortunately, we cannot see the impact of the crisis on such attitudes-which has without doubt affected how much citizens appreciate the EU-because the data stop in 2004. Although this question was not asked after this point, it is nonetheless useful to see how Europeans felt about the possibility of disintegration prior to the crisis-when "things were going well" at the EU level. Indeed, the data we examine here cover the period from the 1970s until 2004, when important steps towards further economic integration were made, such as the Maastricht and Amsterdam Treaties (in 1992 and 1997, respectively) and the circulation of Euro coins (in 2002). Indeed, if citizens perceived integration as beneficial, there should be a sizable amount of them that would indeed feel sorry for the collapse of the Union.

Figure 4 shows that, until a decade ago, while a considerable amount of citizens within the EU would be very sorry to hear that the EU collapsed, an equally large amount would be indifferent to disintegration. We also observe that since the 1990s indifference started rising above $40 \%$ while the percentage of citizens that would feel very sorry if the Union would disintegrate started declining below $40 \%$. In the mid-1990s the trends reversed; interestingly, the decline of those who would mourn the end of the Union is parallel to important integration steps, such as the Maastricht (1992) and Amsterdam (1997) treaties; around the introduction of the common currency (2002) we do observe an upward trend. At the same time, it seems that when the data collection stopped both indifference and sadness were experiencing a parallel increase. Over time, we observe a small increase in the percentage of citizens that would be even relieved if the Union would disintegrate, while those that do not know how to answer this question remain relatively stable over time, around $10 \%$.

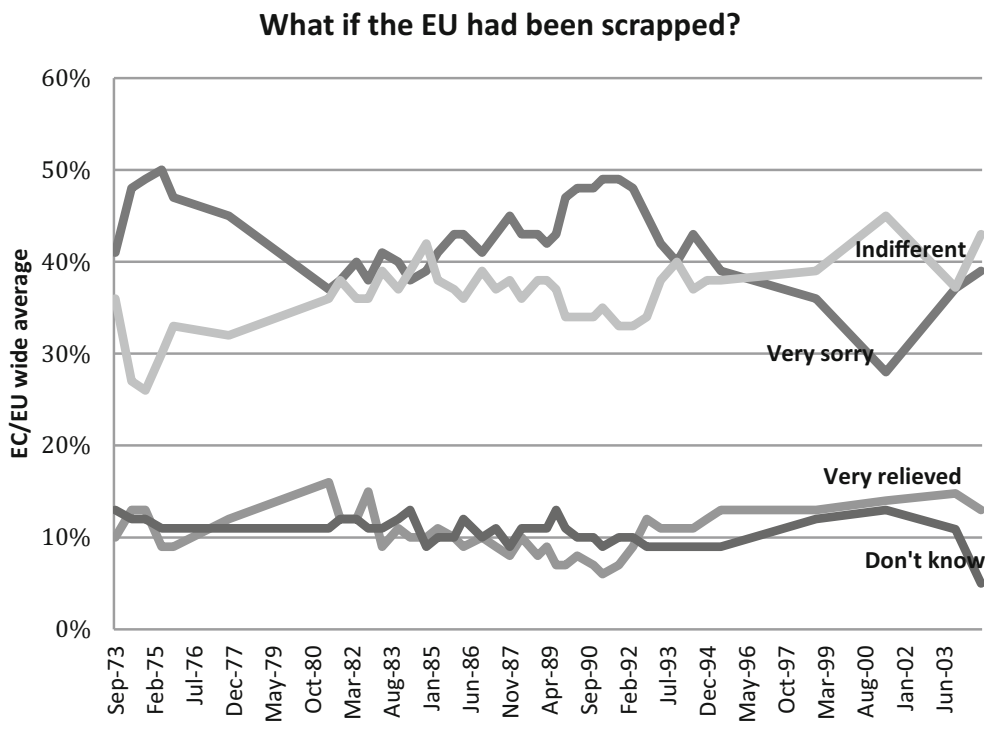

Fig. 4 Attitudes to the disintegration of the European Community/Union during 1973-2004. Source: Eurobarometer 
Citizens' attitudes to disintegration are also related to their perception of the country's membership in the EU but also by their own, personal perception of the EU's role in their life, and the expectations that are bound to this. First, recognition and appreciation of integration by the citizens can be understood by additionally examining the percentages of citizens that have a positive perception of their country's membership. If these percentages decline over time, supportive citizens become fewer and fewer. Figure 5 shows national averages of EU citizens who think that their country has benefited from EU membership both prior to (2007) and during the crisis (2011).

Figure 5 demonstrates a clear decline in the proportion of citizens with a positive perception of EU membership. With the exception of Finland (one the most Eurosceptic MSs) where we observe a slight increase in the percentage of Finns that view EU membership positively, all other MSs experienced decline during the crisis' years. Again, we do not know how this trend evolved after 2011 because we lack more recent data, so we can only speculate that the trend continues downward, given the developments in the Union and its incapacity to solve the crisis until this moment. Recent analyses of trust in the EU (Armingeon and Ceka 2014), which is a different indicator of the EU's relationship with the citizens it is supposed to serve, also portray a worrisome picture.

Second, we also examine how Europeans perceive the (expected) benefits from integration from a personal perspective. Do citizens associate the EU with positive or negative expectations? To answer this question, we examine what the EU means to them personally based on data from 1997 to 2001 . Figure 6 shows percentages of

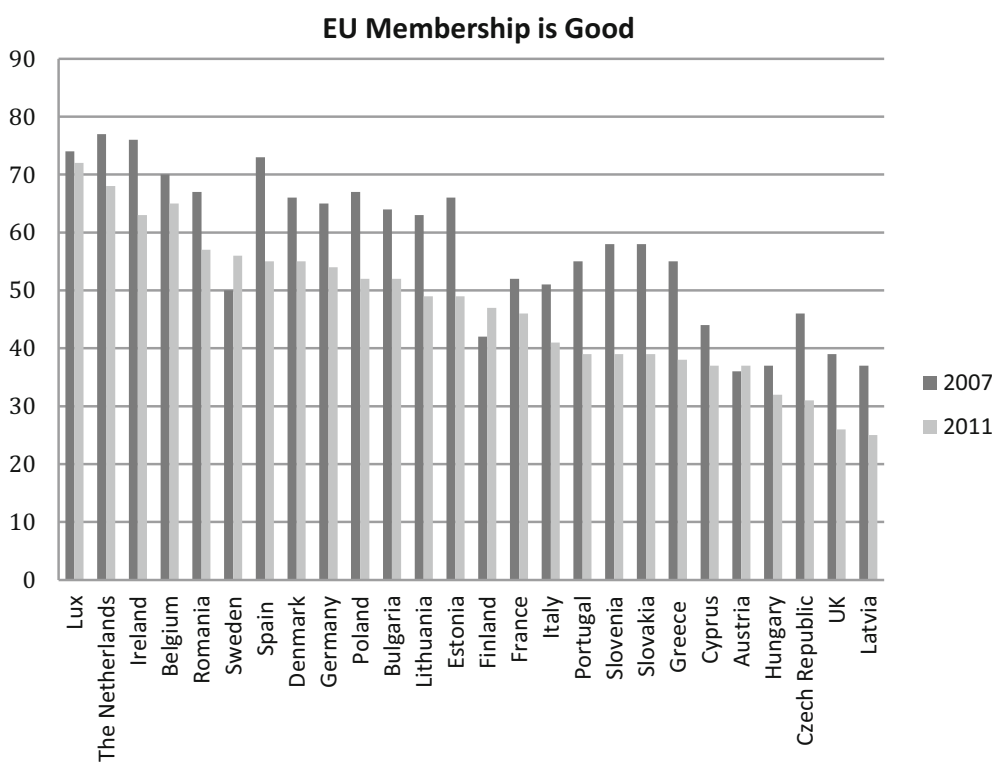

Fig. 5 Perceived (own country's) benefit from EU membership across the EU in 2007 and in 2011. Source: Eurobarometer 


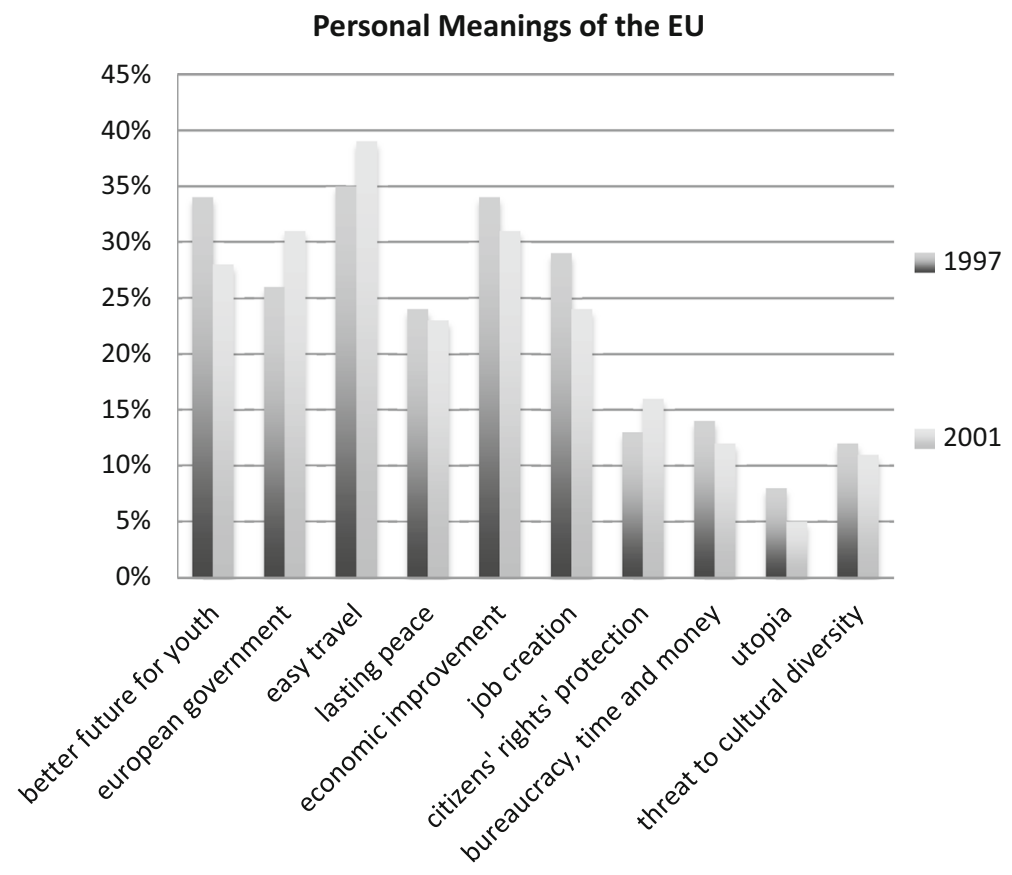

Fig. 6 Personal meanings of the EU in 1997 and in 2001. Source: Eurobarometer

EU citizens for whom the EU has positive and negative connotations. ${ }^{6}$ First, we see that for the majority of the respondents the meaning of the EU was linked to positive expectations: the EU meant facilitating travel, a European government, improving the economic situation in Europe; creating a better future for young people and jobs; ensuring peace and protecting citizens' rights. In sum, the EU meant a lot more than a peace project. For some Europeans, however, the EU presented a risk of losing cultural diversity, while for others it represented bureaucracy, waste of time and money or just an illusory utopia.

When we compare the data from 1997 to that of 2001, we do not see stark differences. Nonetheless, the percentage of those Europeans for whom the EU signified a better future for youths, the creation of jobs and economic improvement as well as the warranty of lasting peace declined. At the same time, the percentages of those who identified the EU with easy travel, a European government and the protection of citizens' rights increased slightly. Those for whom the EU had a negative meaning decreased slightly.

As we lack more recent data, we cannot present an accurate picture of the EU's current reputation. Yet, we suspect that the picture sketched by Fig. 6 has changed radically. First, Eurosceptic parties that oppose the EU out of fear of cultural but also economic losses (e.g., Lefkofridi and Michel 2016) are on the rise. Second, the

\footnotetext{
6 This figure excludes those citizens who did not know how to answer this question (DK), who amounted to $5 \%$ in 1997 and to $8 \%$ in 2001 as well as those for whom the EU meant something else (other), who amounted to $1 \%$ in both years when the question was asked.
} 
economic crisis generated massive unemployment and hindered growth, which, in turn, hurt the image of the EU as an economic solution, or the creator of jobs and of a better future for the young. Third, the refugee crisis in the summer of 2015 led to the partial and erratic suspension of the Schengen agreement and the reestablishment of border controls between EU MSs, the absence of which had facilitated travel.

Furthermore, NF specifically assumed that the primary benefit would be greater security. We take a close look at public preferences regarding the appropriate level of government for security and defense. Though the only data available concerns the period 1989-1995, it is worth examining because this was a crucial period for integration. Key treaties - the Single European Act (1987), the Maastricht Treaty (1992) and the Amsterdam Treaty (1997)—which were signed right before, during and after the period covered by these data were milestones for European integration. Therefore, these data give us a hint about whether mass publics during that decisive period tended to support positively the expansions of its compétences in very 'sensitive' policy areas: if European integration fails to create a feeling of security, the public will be more inclined to believe that security and defense should be dealt with at the national level, without any interference of the EU. On the contrary, if integration makes Europeans feel safer among themselves, the public will be more likely to think that their national government should decide on security and defense matters together with their EU partners. Figure 7 shows that European public opinion is divided on this question: about half of the respondents think that security and defense matters should be decided at the national level (by their own country's government exclusively), while the other half thinks that security and defense should be decided jointly with the EU. While there are small fluctuations over time, it is remarkable that both views are equally strong. Also interesting is the fact that while initially (1989-1990) no respondents claimed not to know how to answer this question, the amount of "don't knows" rises and stabilizes around $5 \%$.

An interrelated question is the extent to which integration impacted on Europeans' identity. Since integration was conceived by its founders as an antidote to nationalism, one would expect that the proportion of EU citizens who perceive themselves as exclusively "national" citizens would decline over time. Figure 8 shows the percentages of EU15 respondents who, in the near future, see themselves as 'national only' (e.g., Belgian, Italian) in 2000 and again in 2010. First, we observe that the national averages vary, ranging from around 20 to $70 \%$ of citizens who identify exclusively with the nation-state (in Luxembourg and the UK, respectively). The change during this decade is small, but there is a general trend to decline. Except for France, Ireland, Spain and the UK, in all other MSs the national average of citizens that perceive themselves as exclusively national decreases, albeit slightly. The EU15 average of exclusively national identity remains above $40 \%$ during a decade of important EU-level developments such as the Treaty of Nice (2001), the European Convention (2002) and the Lisbon Treaty (2009). The picture of a divided EU public in terms of self-perception as exclusively national (Fig. 8) combined with a divided public opinion regarding EU involvement in matters of security and defense (Fig. 7) is telling. Of course, one of the reasons why the national self-perception persists may be the public ignorance about their rights as 


\section{Security and Defence}

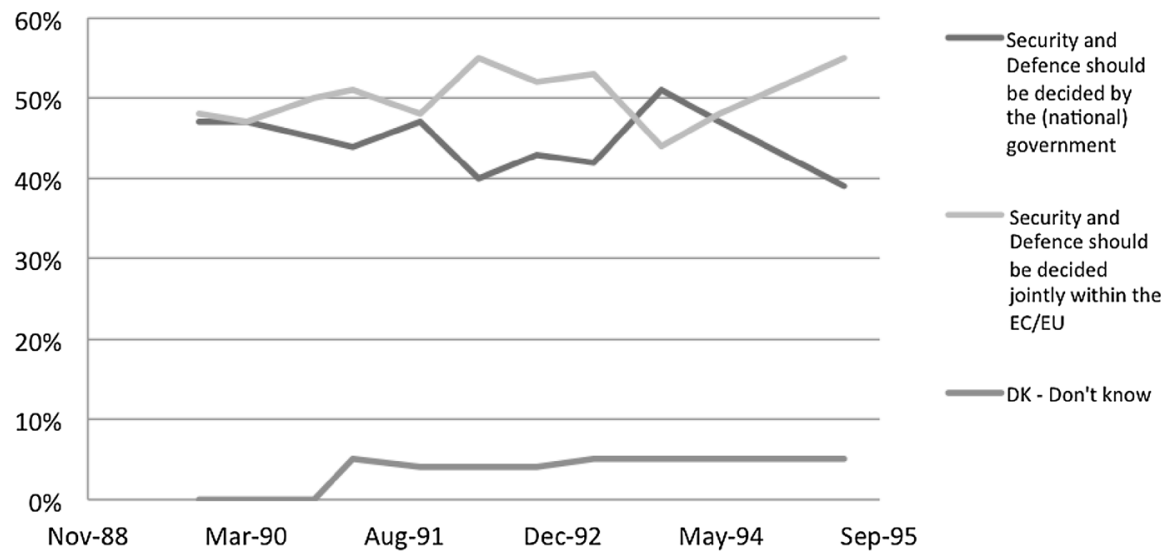

Fig. 7 Public opinion regarding appropriate level of government for security and defense during 1989-1995. Source: Eurobarometer

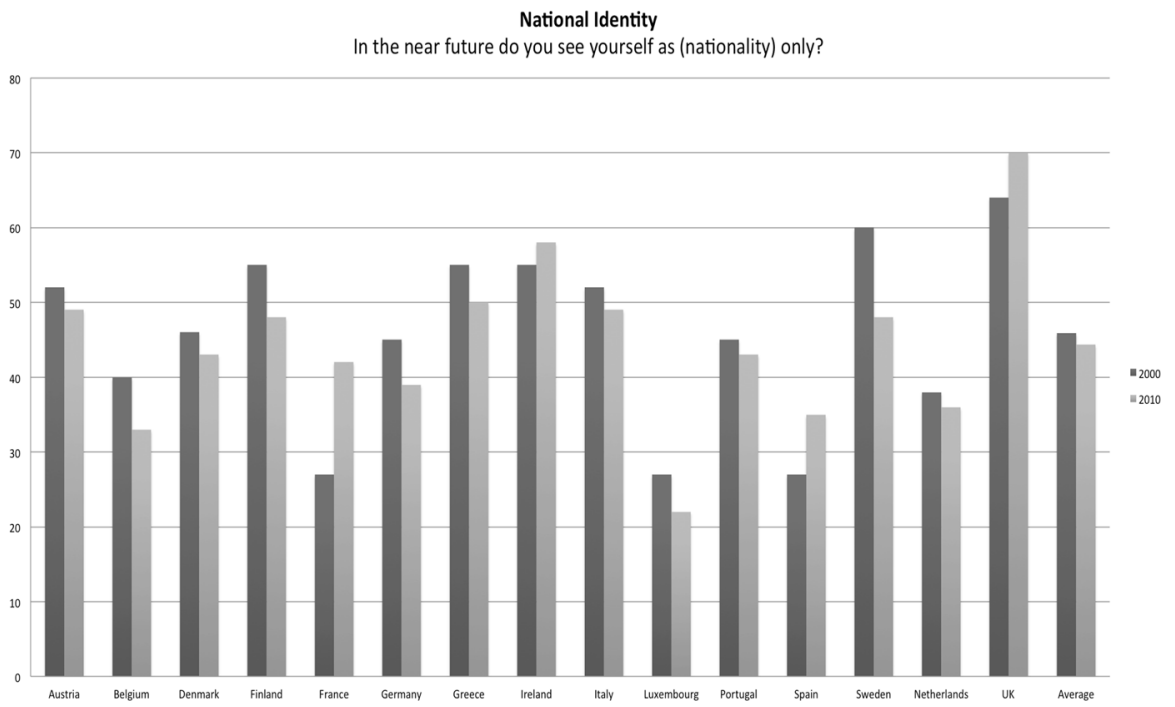

Fig. 8 Exclusively national perception of identity in 2000 and in 2010. Source: Eurobarometer

"EU citizens". It is hard to play-not to mention like-any game if you do not understand the rules.

Indeed, the development of EU citizenship has faced numerous challengesmostly due to the difficulties people encounter regarding getting informed about and exercising their rights as EU citizens. This is what a recent study of European citizenship in times of crisis by Carlos and Vintila $(2014,29)$ observes and it concludes that "the social and political panorama in the EU in 2013 is a long way from the initial optimism that accompanied the formal introduction of EU 
citizenship 20 years ago". Since the EU system is not taught in primary schools (as national political systems are) EU citizens are deprived of the information that sets the fundaments of one's belonging to a political community i.e.: knowledge of how the system of governance (rules, institutions, procedures, etc.) that affects their everyday life.

\section{b. Economic Prosperity}

Economic prosperity has been one of integration's key goals. One way of assessing the distribution of benefits within the Union as well as trends of economic convergence (Suppositions I.2 and I.6) is to look at the index of economic discomfort, unofficially known as "Okun's Misery Index". This indicator specifies the level of economic malaise as the unweighted sum of the annual inflation and unemployment rate. Lechmans' (2009) calculations of this index in EU MSs (2001-2007) prior to the current crisis revealed mixed variation over time and across states. According to Lechman (2009) discomfort has been lowest in Austria, Denmark, and the Netherlands, and highest in Eastern European countries, who were the last to join the Union; that said, since these countries joined, their economic discomfort decreased. Interestingly, Germany is the only strong economy whose index approaches the indices of much weaker economies, such as Greece or Portugal. We suspect that this is because Germany has for a long time engaged in wage dumping in order to acquire a competitive advantage vis-à-vis other MSs. Around $30 \%$ of workers in Germany work for hourly remuneration that is below the poverty level (BBC 2013).

Since we lack data to demonstrate the evolution of misery indices during the crisis, next we consider trends of a key component of this index: unemployment. Figure 9 visualizes unemployment rates within the Union and the Eurozone over time compared to that of US and Japan as well as current rates across EU MSs. Firstly, the top graph shows unemployment trends in the EU and the Eurozone (top lines) during 2000-2015, compared to those of the US and Japan (bottom lines). In detail, we see that, contrary to Japan's stability of low unemployment over time, the US and the EU as well as the Eurozone experienced a rise in unemployment rates at the beginning of the crisis in 2009. However, the parallel evolution of the US, the EU and the Eurozone unemployment rates was very short-lived; since 2010 the US trend is downward, the EU is upward. This very stark divergence is interesting because Europeans and Americans chose very different methods to deal with the economic crisis (see also below, where we discuss the role played by experts in this regard).

Secondly, the bottom graph of Fig. 9 demonstrates current levels of unemployment (2014-2015) in each of the MSs. Here we see tremendous differences: unemployment rates range from $4.7 \%$ in Germany to $22.5 \%$ in Greece. This sharp rise has, of course, impacted levels of poverty. As mentioned above, we lack data on the Okun index in the EU for recent years; however, at least for the Eurozone members, inflation is regulated by the European Central Bank (ECB), not by the MSs. So based on the aforementioned rise of unemployment, it is normal to expect that misery may have become more salient in some MSs today. For instance, in the hardest hit MSs poverty has experienced dramatic increases since the beginning of 


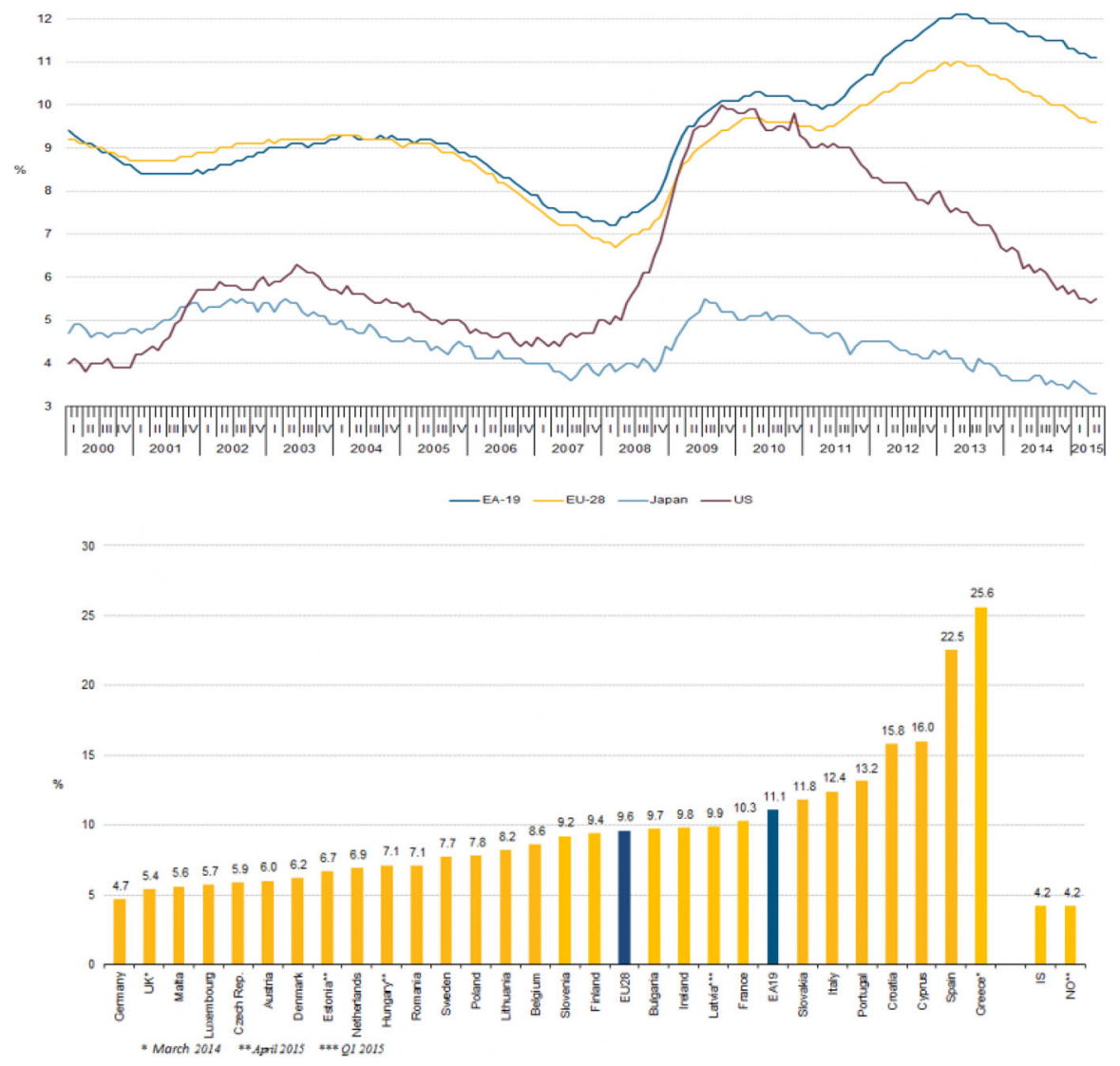

Fig. 9 Unemployment. Top graph: trends in unemployment over time in the EU and the Eurozone (two top lines), the US (line in the middle) and Japan (bottom line) during 2000-2015. Bottom graph: current unemployment in each of the EU MSs (2014-2015). Sources: Eurostat/Knoema

the crisis. A Report by the Director of the National Bank of Greece in 2013 shows that: in 2011 (already 2 years into the crisis) $21.4 \%$ of the Greek population lived below the poverty line, while $31 \%$ was at its threshold of poverty and, and hence, threatened by social exclusion; the amount of people living in households where no one was employed increased by $53.7 \%$ between 2010 and 2011 (Bank of Greece 2013: 101-3).

Last but not least, and in relation to proposition I.6 we should note since the onset of the crisis the EU has been performing very poorly in terms of growth, especially when compared to the US and Japan (Balcerowicz et al. 2013). It should be noted, however, that some counties who had experienced decline in growth earlier (Sweden in mid-1990s, Germany in 2000s) have witnessed an increase ever since-a trend that continued through the crisis. On the contrary, Italy has had a steady decline in growth since the mid-1990s. Greece, on the other hand, experienced a downward trend until the 2000s, but then boomed until the crisis hit, and growth sharply declined ever since (ibid.). Since the beginning of the crisis, 
the group of "growth leaders" in the EU consists of Germany, Sweden and many countries that joined the EU very recently (Bulgaria, Estonia, Latvia, Lithuania, Malta, Poland and Slovakia).

All the above contradicts neo-functionalist hypotheses that the distribution of benefits would not be skewed, and that MSs would converge in terms of economic performance and social protection. We are currently witnessing exactly the opposite: in the name of increasing competitiveness and making the labor market more flexible, troubled-countries' governments have pursued the reduction of wages and pensions. Within the framework of austerity applied to Greece, for instance, the measures implemented in the context of the international loan mechanism (Memoranda of Understanding, MoU) have been combined with violations of trade union and collective bargaining rights (ILO 2012). The situation of labor in Greece after the Troika therapy is entirely different from other MSs, such as France or Austria-so by no means can we speak of convergence of social protection within the EU.

\section{The Role and Conflicts of Epistemic Communities}

Yet, if the Union is performing as badly in terms of growth, unemployment, and convergence, the question is raised: what has been the role played by experts? To explore Supposition I.4, we review evidence of the behavior of the epistemic community in which the neo-functionalist framework put so much faith.

The role played by experts in EU policy-making is well established in the literature (Radaelli 1999), from environmental (Zito 2001) to security issues (Davis Cross 2007), the creation of the EMU (Verdun 1999) and the convergence of competition policy Waarden and Drahos (2002). At the same time, a recent empirical study by Gornitzka and Sverdrup (2011) shows that, while the Commission relies on a large expert group system for developing, monitoring and implementing EU Policy, the principal actors in this expert group system are officials of national governments. National administrators and national authorities competent on the policy issue of concern constitute $69.8 \%$ and $34.1 \%$ respectively of experts participating in Commission expert groups, while regional and local administration officials amount to $8.1 \%$. At the same time, scientists and business/industry constitute 33.3 and $28.5 \%$, respectively. This study observes a much smaller participation in the Commission's expert group system of NGOs (16.7\%), practitioners $(12.7 \%)$, social partners/unions $(11.8 \%)$, consumers $(8 \%)$ and international organizations $(2.2 \%)$.

Expertise has been contrasted with politicization (Radaelli 1999) and it seems that, at least for most of the integration process, conflicts were internalized and resolved without reaching the outside, political world. ${ }^{7}$ It is very important to note here that prior to the crisis, a coherent and dedicated group of neoliberal economists came to dominate both regional and global international financial institutions. This global epistemic community has resulted in policy choices becoming increasingly determined by their assumptions, models and policies (Chwieroth 2007). As

\footnotetext{
7 A notable exception to this rule was the Bolkenstein directive on the liberalization of services, which was criticized by left-wing organizations as a route towards competition among workers, social dumping and income decline.
} 
Rosenhek (2013: 23) explains the "interpretative plots of the crisis were not offered by outsiders, but rather by established and powerful actors, such as the Fed and the ECB, with recognized expertise and high epistemic authority". Notwithstanding key differences regarding their positioning the political economy, their institutional legacy and their definition of the main task of central banks, the diagnoses, notions and themes offered by the Fed and the ECB were very similar (ibid.)

During the crisis, the neoliberal epistemic community in Europe by and large internalized its conflicts and has thus had a very consistent approach in favor of austerity. Experts advocated fiscal balance and budgetary austerity with the assumption that this would result in monetary stability and a shift of available investment from public institutions to private firms, which in turn was supposed to have triggered a general expansion of employment, production and prosperity. So much epistemic authority did these experts have, that they were even appointed to govern troubled countries (vide Monti in Italy and Papademos in Greece). Indeed, the solution of the crisis was thought of as a technocratic issue, as a matter of fiscal consolidation, which could only occur under the "objective" rule of technocrats, who were not constrained by electoral clienteles. Parties, on the other hand, avoided as much as possible to get their hands dirty with cutting their clienteles' salaries, pensions, or even their jobs in order to bring the common household in order. In the case of Greece, for example the austerity measures lasted for 6 years although they resulted in GDP shrinking by $25 \%$ over 4 years, unemployment rising to $25 \%$ (and youth unemployment to $50 \%$ ); yet, the epistemic community was insisting that the same kind of medicine be continued.

The NF Suppositions regarding the role of experts as well as their conflicts (I.4) seem to be confirmed. However, on the issue of whether 'austerity as the right medicine', the trans-Atlantic epistemic consensus had been recently challenged. The US pursued very different policies compared to the EU (e.g., invested money to create jobs and growth) and was much more successful in getting through the crisis and reversing unemployment trends (see Fig. 9). The rupture between US and EU neoliberal economists is also reflected in the fact that the International Monetary Fund (IMF) published a report that clearly says that Greek debt is not sustainable (after years of not having expressed a clear position ${ }^{8}$ ) in an effort to shape political developments during the negotiations of the third Greek bailout in 2015. The timing of the publication was as critical as the content: the IMF management proposed to publish this report on short notice during the meeting of the International Monetary Fund's board on the Wednesday before the Greek referendum of Sunday July 5, 2015. ${ }^{9}$ Among Greece's EU partners, the creditor-countries rightly feared its

\footnotetext{
${ }^{8}$ An IMF report issued in Summer 2013 discussed the sustainability of the Greek debt and admitted that the IMF made mistakes in the Greek case (The Wall Street Journal 2013); it did not, however, recommend a change in policy direction.

${ }^{9}$ The Greek Radical Left-led Government (SYRIZA-ANEL) was elected in January 2015 with debt relief as its key goal. Although this government, like all others before, conceded (ideological) defeat by accepting all creditors' terms about austerity measures in exchange of financial assistance, the creditors also kept on refusing to put the debt issue on the negotiating table. The Greek government thus announced a referendum to be held on July 5, 2015: Greeks, 6 years under the austerity treatment already, were to accept or reject the creditors' proposal for further austerity measures. The referendum was decisive for Greece but also Europe (see below: politicization and conflict).
} 
potential impact on the Sunday vote; but they were heavily outnumbered. However, the US members of the IMF, who were in favor of its publication, insisted on it becoming public (Reuters 2015a). It is important to note that top economists from the US have been very critical of the kind of economic mantra Europeans have been following and vociferously contributed to the debate on the Greek referendum. They even encouraged the Greeks to vote 'no' to more austerity (Galbraith 2015; Krugman 2015; Stiglitz 2015), even contrary to the recommendation by the President of the Commission Jean-Claude Juncker (2015) (and statements by the President of the European Parliament Martin Schulz and the President of the Eurogroup Jeroen Dijsselbloem) in favor of a 'yes' vote. In detail, however, while American experts were advising the Greek people to resist further austerity because they assessed it as a wrong policy direction, the political leadership of EU institutions (Commission, Parliament and Eurogroup) threatened with Grexit.

\section{Incremental Integration and Pacta Sunt Servanda}

Suppositions I.5 and I.7 concern the respect for EU decisions and incremental integration, respectively. Here we will put special emphasis on legislation and the activity of the European Court of Justice (ECJ), which relates to both neofunctionalist hypotheses, namely the incremental pace of integration and the respect for the legislation that is produced. Taken together, they help us capture integration in terms of both quantity and quality.

To begin with, the incremental trend is reflected in the fact that the EU's policy competences have been ever expanding: not just more EU policies, but also in more and more policy areas. Throughout time, the EU acquis communautaire-which any country wishing to join the EU must incorporate into its national system of governance-has increased in a number of important policy areas, involving both deregulation (e.g., competition policy) and regulation (e.g., environment). When the number of EU laws peaked in the 1980s (over 14,000 instruments), Commission president Delors even predicted that within 10 years " $80 \%$ of economic legislation, and perhaps also fiscal and social legislation, would be of EC/EU origin" (Miller 2010). Estimating this number is notoriously difficult, ${ }^{10}$ and the more integration advances, the more difficult it becomes to disentangle EU-induced from nationally induced law. This is also due to sectoral interdependence; integration in one policy sector has led to 'technical' pressures pushing for integration in other sectors (Haas 1958; Schmitter 1969).

Firstly, the number of new cases brought to the ECJ has increased over time, which reflects the production of ever more legislation (Court of Justice 2010). According to official statistics, the Court has been more and more active over time, although not in a perfectly linear fashion. New cases have been expanding and so have completed and pending cases between 2007 and 2011 (Court of Justice 2010).

\footnotetext{
10 While there is no "totally accurate, rational or useful way" of calculating the percentage of national laws that are based or influenced by the EU, related estimates of the proportion vary across members and range from 6.3 to $84 \%$ (Miller 2010).
} 
Figure 10 displays the number of cases and judgments before the ECJ during the period 1970-2010 — and illustrates this increasing trend.

Secondly, studies of implementation of EU law show that some states comply in most cases; whereas, others delay transposition, be it due to domestic political conflict over the content of the policy or due to neglect (Falkner et al. 2007; Falkner and Treib 2008). When we examine the bulk of completed cases of failure to fulfill obligations we see that while most MSs have engaged in non-compliance, for some the situation is more pronounced (Court of Justice 2010). Whereas very few MSs do not figure on the statistics, more than half had trouble with fulfilling their obligations; the champions of 'failure to comply' during 2007-2011 were, in ranked order: Italy, Spain, Greece, Belgium, Luxembourg, Portugal, France, Germany, Ireland, Austria, Sweden, Poland, Czech Republic, the Netherlands, UK and Finland; all others have negligible percentages but this is primarily because they had transposed most of the acquis before joining. Figure 11 displays the actions against EU15 MSs during 1952-2010. There is variation across MSs and some perform better than others in implementing EU decisions. Denmark, Sweden and Finland stand out as the least troubling countries, while Italy stands out as the member with the highest number of actions, followed by France, Greece and Belgium. Note that except for Greece, all others in this group of misbehaving members are founding MSs.

Thirdly, often the same violations are treated differently, which could impact the perception of fairness of integration (thus, connecting with Supposition II.6). At the beginning of the crisis there was much talk about lack of some MSs' respect towards the Stability and Growth Pact (SGP). However, such violations had occurred previously and had been tolerated politically: when Germany and Portugal (2002) and then soon again later (2003) Germany and France were the first to violate the SGP rule ${ }^{11}$ the Council of ministers did not resort to punitive measures, despite recommendations by the Commission. Violations of the Pact were neither admonished, nor were violating members coerced to conform to the rule. Based on an understanding of unfavorable economic conditions, states violating the Pact were given flexibility and time to correct their deficits. As a result, the EU's capacity for legal coercion was substantially weakened.

However, the situation was very different a couple of years later. This time it was not the hegemon, but a group of peripheral weaker economies who had breached the rules; and it was not just EU institutions, but also financial markets and international rating agencies who were involved (this, in turn, connects to II.5 on the role played by exogenous factors in causing and solving the crisis; for a discussion, see Lefkofridi and Schmitter 2015). That said, neo-functionalism assumed crises to be endogenous and its solutions as well (see however II.5 on exogenous shocks); in dealing with the Greece, a Eurozone member, the Council decided voluntarily to involve the IMF in the EU's internal business. The so-called "Troika" composed of the European Commission, the ECB and the IMF was the institution in charge, whose role is to make sure that $\mathrm{MoU}$ are honored through constant surveillance and close monitoring, including on-site visits and controls.

11 Detailed figures are provided by Morris et al. (2006). 


\section{Cases and Judgements before the ECJ}

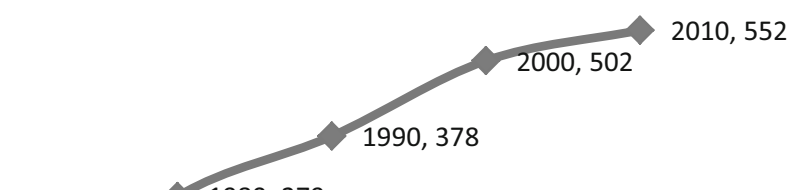

1980, 279

1970,79

$\begin{array}{lllllll}1960 & 1970 & 1980 & 1990 & 2000 & 2010 & 2020\end{array}$

Fig. 10 Number of cases and judgments before the ECJ. Source: Court of Justice (2010)

\section{Actions against EU Members States 1952-2010, EU15}

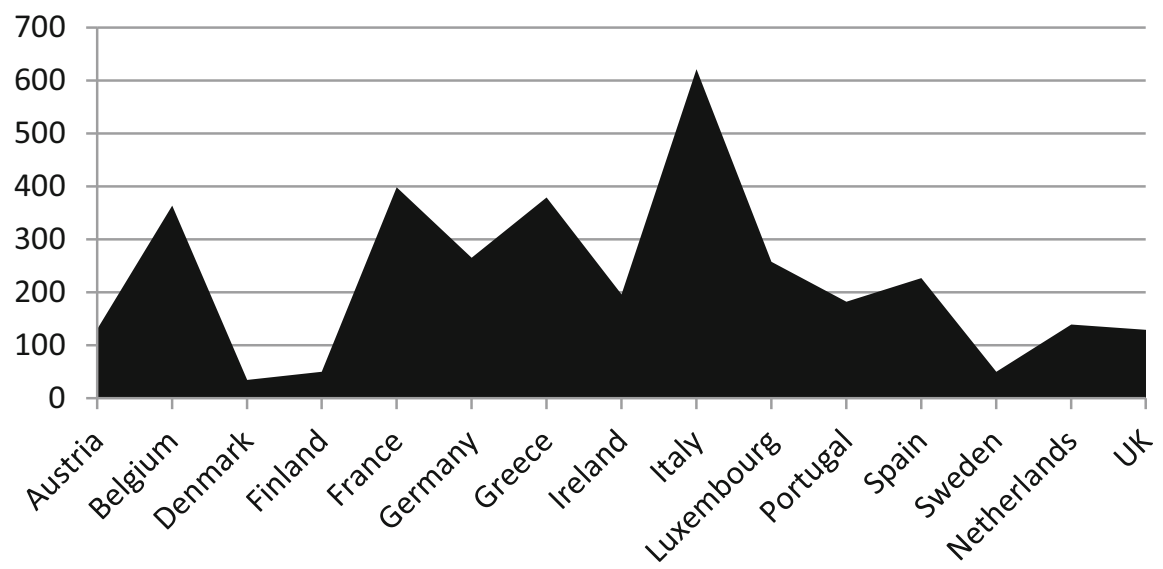

Fig. 11 Number of actions against a EU MS (1952-2010). Source: Court of Justice (2010)

\section{Conflict and Politicization}

Throughout the decades, the problem regarding the politicization of Europe was that it was nationally bounded, and controlled by national political parties. In terms of the functions parties are supposed to play in representative democracies they have—consistently_played a very irresponsible role, either by depoliticizing Europe or by demonizing Brussels (Lefkofridi and Schmitter 2015). Prior to the crisis, only parties at the extreme poles have mobilized around the issue of European integration, albeit for very different reasons. These parties do not politicize integration in order to defend it but to criticize it, and there are nuances and varied 
degrees of Euroscepticism within the radical right and left camps. Some Eurosceptic parties reject the EU altogether; whereas, others want to keep it but change either its policies, or its polity. Among the mainstream, pro-European parties, there has been little or no effort to encourage public debates-neither about the benefits of European integration nor about how to address the EU's problems and deficits. Prior to the crisis, the pro-EU mainstream had thus swept EU affairs under the carpet; when the crisis began, this very elite felt threatened by the populist Eurosceptics and indulged in a kind of rhetoric that had strong nationalist undertones. Five years into the crisis, when European elections were held in 2014, nationalist-Eurosceptic parties thrived. Although their potential for impact on EU-level legislation may be overestimated (Brack 2015), they do affect European developments by influencing the behavior of mainstream, typically pro-EU parties behavior.

This is true for most EU MSs, but even for the Germany, who stands out as the country that has benefited the most from economic (and monetary) integration as well as from the Greek crisis (Heinisch 2015; Dany et al. 2015). Instead of revealing these facts to the German public, however, the traditionally pro-European CDU/ CSU opted for a nationalistic moralizing narrative against the South, when, actually, it is Germany's beggar-thy-neighbor policies that endanger the Eurozone and make it impossible to rebalance its balance-of-payments (Spiecker 2015). Moreover, while German historians reminded their Chancellor that their country has benefited from debt relief many times in its history, the Eurozone declared itself ready for a Grexit in July 2015. More specifically, Germany even proposed a "time out" from the Eurozone, an exit for an undefined period-an unprecedented spill-back designed exclusively for the case of Greece, but which could prove contagious. This was a highly risky strategy, not least because the UK is preparing for a referendum on Brexit.

At first sight then, developments seem to contradict some of the expectations outlined in I.8. During the crisis, however, the emergence of greater conflict with regard to European integration, its policies and its increased autonomy did result in ever more politicization, i.e., the mobilization of more and more EU citizens paying attention to the integration process and expressing a greater diversity of opinions about it. We saw an unprecedented mobilization of civil society: the citizens took to the streets to join demonstrations against austerity and the solutions pursued at the EU and national levels that increase inequality and hurt the middle and lower classes (Accornero and Pinto 2015; Beichelt et al. 2014; Della Porta 2012). Only the amount of protest events is enough evidence that many European citizens are concerned with European integration and also that they are not happy with the policies pursued. Europe became even more politicized since the election of the Greek radical left party SYRIZA in January 2015, whose first half year in power produced turbulent relations between EU partners and Greece.

Perhaps the most positive of these, admittedly dramatic, developments is that Europeans got thirsty for EU news, about what EU officials and political leaders in other EU countries say or do (Poschardt 2015). Europeans are not as indifferent or ignorant about EU issues as (national) politicians in their (national) parties might have wished for. The days before the Greek referendum even saw thousands of Europeans taking to the streets to express their solidarity with the Greek people, 
encouraging them to vote 'no' in the hope that this would force EU leaders to change policy direction (Reuters 2015b), while prominent academics from all around the world wrote Op-eds framing the Greek problem in European terms. They warned that in case of Grexit the future of the Eurozone would be at stake, not because Greece matters much in the EU economy but because it would set a precedent that would make the EU more vulnerable to the global market forces in the future. This could also affect the performance of the strongest economies of the Eurozone, given the importance of the currency for trade. However, because national parties feared it could jeopardize their vote optimization strategies, they carefully avoided the discussion about the sustainability of public debt. European solidarity was under test during the economic crisis.

Unity and solidarity among MSs was tested again during the accommodation of refugees. ${ }^{12}$ Germany would this time seek cooperation with all other MSs in dealing with the Syrian war refugees, who arrived en masse at the Greek island of Lesbos in the hope of finding shelter in the EU. The issue caused bitter divisions between as well as within the MSs, but also within parties. Notwithstanding nationalchauvinism being very prominent in political elites' discourse, large parts of European publics were-at least initially_welcoming of the refugees and of the pursuit of European policy solutions.

\section{Conclusion}

In this article, we have used neo-functionalism as an analytical framework to explore conditions that would favor or hinder disintegration. We outlined a series of Suppositions and Hypotheses, which we then assessed on the basis of a variety of available data sources and related scholarly research. As this is an exploration of many different expectations simultaneously, we could not go in detail into each and every hypothesis. The empirical picture has been painted with a broad brush, which focused on national and EU averages. Future research should examine these hypotheses by differentiating more between but also within MSs; for instance, what is the exact picture of benefits if we disaggregate European publics into different socioeconomic groups?

Despite its limitations, this study provides a pioneering analysis of (in-)fertile conditions for disintegration in Europe. In accordance with NF we observe that: integration has been by and large incremental and that interdependence among MSs did indeed increase. Significant parts of the publics in all MSs recognized the benefits of integration. Experts did play a key (even if not always positive) role. With the crisis integration did get intensely politicized. However, contrary to neofunctionalist hypotheses, the distribution of benefits was skewed; in particular the German economy stands out as the key beneficiary in trade-although the German worker may not really "feel" this success due to decades of low wages.

\footnotetext{
12 Though national political leaderships in general have not lived up to the expectations of the kind of integration they themselves pursued with their decisions, among the hardliners against the Greek government and the sharing the "refugee burden" are the newest and poorest among the Eurozone members. The latter wished to join the EU and the Eurozone, but did so at its most turbulent times.
} 
Furthermore, compliance has varied across time and countries-and so have the consequences for violations of the rules. In general, policy outputs at the time of writing (e.g., rising unemployment, lack of convergence) contradict the expectations of both NF and the EU citizens in terms of economic improvement or a better future for the young. In Southern Europe highly qualified young people are facing massive unemployment. Such results not only go against NF, but they also suggest that there might be some corresponding increase in the likelihood that the EU could disintegrate. Indeed, the EU is not in a good shape. Even worse, nationalism, chauvinism and racism-all maladies that European integration was supposed to cure-have re-emerged on the European continent. Of course, the EU is a moving target-all the more so in the midst of its most severe crises to date. Whatever one might conclude on the basis of its response so far might well be annulled by future developments.

Acknowledgments Open access funding provided by Paris Lodron University of Salzburg.

Open Access This article is distributed under the terms of the Creative Commons Attribution 4.0 International License (http://creativecommons.org/licenses/by/4.0/), which permits unrestricted use, distribution, and reproduction in any medium, provided you give appropriate credit to the original author(s) and the source, provide a link to the Creative Commons license, and indicate if changes were made.

\section{References}

Accornero, G., and P. Ramos Pinto. 2015. 'Mild Mannered'? protest and mobilisation in Portugal under austerity, 2010-2013. West European Politics 38(3): 491-515.

Agur, I., E. Dorrucci, and F.P. Mongelli. 2007. How did European institutional integration and intraEuropean trade interact? Economie internationale 1(109):107-146. http://www.cairn.info/revueeconomie-internationale-2007-1-page-107.htm. Accessed 15 June 2015.

Armingeon, K., and B. Ceka. 2014. The loss of trust in the European Union during the great recession since 2007: The role of heuristics from the national political system. European Union Politics, 15(1):82-107.

Balcerowicz, L., A. Łaszk, A. Rzońca, and L. Kalina. 2013. Economic growth in the European Union. Lisbon Council.

Bank of Greece. 2013. Director's report for 2012. Athens: Bank of Greece, 02.2013. http://www. bankofgreece.gr/BogEkdoseis/ekthdkth2012.pdf. Accessed 04 March 2014.

British Broadcast Corporation/BBC. 2013. Belgium protests over German low pay in EU complaint. 09.04.2013. http://www.bbc.com/news/world-europe-22080862. Accessed 01 Nov 2015.

Beichelt, T., I. Hahn-Fuhr, F. Schimmelfennig, and S. Worschech. 2014. Civil society and democracy promotion. London: Palgrave Macmillan.

Brack, N. 2015. Populist and radical right parties at the 2014 European parliament elections: Much ado about nothing? In Parliaments, public opinion and parliamentary elections in Europe, eds. Fasone, C., C. Fromage, and Z. Lefkofridi, 92-104. MWP 2014/5. Florence: European University Institute.

Chwieroth, J. 2007. Neoliberal economists and capital account liberalization in emerging markets. International Organization 61: 443-463.

Carlos, C. and D. Vintila. 2014. La ciudadanía europea en tiempos de crisis". In El estado de la Unión Europea: La ciudadanía europea en tiempo de crisis, ed. López Garrido, D., 19-31. Fundación Alternativas \& Friedrich-Ebert-Stiftung http://www.fundacionalternativas.org/public/storage/ publicaciones_archivos/57d96229c46cc02b24e72395dad8842e.pd. Accessed 16 Dec 2015.

Court of Justice. 2010. Annual report—statistics. http://curia.europa.eu/jcms/upload/docs/application/pdf/ 2011-05/ra2010_stat_cour_final_en.pdf. Accessed 01 July 2015. 
Dany, G., R. Gropp, and G. von Schweinitz. 2015. "Germany's benefit from the greek crisis," IWH Online-Leibniz Institut für Wirtschaftsforschung Halle. http://www.iwh-halle.de/d/publik/ iwhonline/io_2015-07.pdf. Accessed 17 Dec 2015.

Davis Cross, M.K. 2007. An EU homeland security? Sovereignty vs. supranational order. European Security 16(1):79-97.

Della Porta, D. 2012. Critical trust: Social movements and democracy in times of crisis. Cambio 2:33-43.

Falkner, G., and O. Treib. 2008. Three worlds of compliance or four? The EU-15 compared to new member states. JCMS Journal of Common Market Studies 46(2): 293-313.

Falkner, G., M. Hartlapp, and O. Treib. 2007. Worlds of compliance: Why leading approaches to European Union implementation are only 'sometimes-true theories'. European Journal of Political Research 46(3): 395-416.

Haas, E.B., and P.C. Schmitter. 1964. Economics and differential patterns of political integration: Projections about unity in Latin America. International Organization 18(04): 705-737.

Haas, E.B. 1958. The uniting of Europe: Political, social and economic forces. Stanford: Stanford University Press.

Heinisch, R. 2015. "Auf dem Weg zu einem deutschen Europa? Eine internationale Perspektive." In Interdisziplinäre Europastudien: eine Einführung, eds. Liebert, U and J. Wolff, 347-368. Springer Fachmedien, Wiesbaden.

Gornitzka, A., and U. Sverdrup. 2011. Access of experts: Information and EU decision-making. West European Politics 34(1): 48-70.

Galbraith, J.K. 2015. Only the 'no' can save the euro. Social Europe, July 4, 2015. http://www. socialeurope.eu/2015/07/greece-only-the-no-can-save-the-euro/. Accessed 04 July 2015.

International Labor Office/ILO. 2012. 365thReport of the Committee of Freedom of Association, GB.316/ INS/9/1. Geneva: 316th Session, 01-16.11.2012. http://www.ilo.org/wcmsp5/groups/public/—ed_ norm/_relconf/documents/meetingdocument/wcms_193260.pdf. Accessed 25 Jan 2014.

Juncker, J.C. 2015. SPEECH/15/5274 June 29, 2015. http://europa.eu/rapid/press-release_SPEECH-155274_en.htm?locale=en. Accessed 06 July 2015.

Krugman, P. 2015. The conscience of a liberal: austerity arithmetic. New York Times, July 5, 2015. http:// krugman.blogs.nytimes.com/2015/07/05/austerity-arithmetic/. Accessed 07 July 2015.

Lechman, E. 2009. Okuns and Barros Misery Index as an alternative poverty assessment tool. Recent estimations for European countries. Germany: University Library of Munich.

Lefkofridi, Z. and E. Michel. 2016. The electoral politics of solidarity. In The strains of commitment: the political sources of solidarity in diverse societies, eds. Banting, K. and W. Kymlicka, Oxford University Press (forthcoming).

Lefkofridi, Z., and P.C. Schmitter. 2015. Transcending or descending? European integration in times of crisis. European Political Science Review 7(01): 3-22.

Miller, Vaughne. 2010. How much legislation comes from Europe? Economic Indicators 7(10). House of Commons Library, Research Paper 10/62, ISSN 1368-8456.

Milward, A. 1992. The European rescue of the nation-state. London: Routledge.

Morris, R., H. Ongena and L. Schuknecht. 2006. The reform and implementation of the stability and growth pact, Occasional Paper Series No. 47/June 2006. Frankfurt: European Central Bank, https:// www.ecb.europa.eu/pub/pdf/scpops/ecbocp47.pdf. Accessed 07 July 2015.

O’Neill, J., and A. Terzi. 2014. Changing trade patterns, unchanging European and global governance. Bruegel Working Paper 2014/02.

Poschardt, U. 2015. Die Krise macht uns jetzt zu wahrhaften Europäern. Die Welt. July 3, 2015. http:// www.welt.de/debatte/kommentare/article143520903/Die-Krise-macht-uns-jetzt-zu-wahrhaftenEuropaeern.html. Accessed 07 July 2015.

Radaelli, C.M. 1999. The public policy of the European Union: Whither politics of expertise? Journal of European Public Policy 6(5): 757-774.

Reuters. 2015a. Exclusive: Europeans tried to block IMF debt report on Greece: sources. http://www. reuters.com/article/2015/07/03/us-eurozone-greece-imf-idUSKCNOPD20120150703. Accessed 03 July 2015.

Reuters. 2015b. 'No more looting': Thousands rally across EU to express solidarity with Greece. http://rt. com/news/271582-europe-greece-rallies-support/. Accessed 07 July 2015.

Rose, A.K. 2000. One money, one market: the effect of common currencies on trade. Economic Policy, A European Forum 30: 7-33.

Rose, A.K. 2001. Currency unions and trade: The effect is large. Economic Policy, A European Forum 33: 449-457. 
Rose, A.K. 2004. A meta-analysis of the effects of common currencies on international trade, NBER Working Paper 10373.

Rosenhek, Z. 2013. Diagnosing and explaining the global financial crisis: Central banks, epistemic authority, and sense making. International Journal of Politics, Culture, and Society 26(3): 255-272.

Sadeh, T. 2014. The euro's effect on trade. European Union Politics, 15(2):215-234.

Schmitter, P. 1969. Three neo-functional hypotheses about international integration. International Organization 23(01): 161-166.

Schmitter, P.C. 1970. Central American integration: Spill-over, spill-around or encapsulation? JCMS Journal of Common Market Studies 9(1): 1-48.

Schmitter, P.C. 2004. Neo-neofunctionalism. In European integration theory, ed. A. Wiener, and T. Diez. Oxford: Oxford University Press.

Schmitter, P.C. 2012. A way forward? Journal of Democracy 23(4): 39-46.

Spiecker, F. 2015. Konfusion von Links Bis Rechts: Was Soll Griechenland Tun? Flassbeck-Economics, 31 Jan 2015. http://www.flassbeck-economics.de/konfusion-von-links-bis-rechts-was-sollgriechenland-tun. Accessed 07 Aug 2015.

Stiglitz, J. 2015. How I would vote in the Greek referendum. The Guardian. June 29, 2015. http://www. theguardian.com/business/2015/jun/29/joseph-stiglitz-how-i-would-vote-in-the-greek-referendum. Accessed 05 July 2015.

The Wall Street Journal. 2013. IMF concedes it made mistakes on Greece. June 5, 2013. http://www.wsj. com/articles/SB10001424127887324299104578527202781667088. Accessed June 10 July 2015.

Verdun, A. 1999. The role of the Delors Committee in the creation of EMU: An epistemic community? Journal of European Public Policy 6(2): 308-328.

Vollard, H. 2008. A theory of European disintegration. In 4 h Pan European Conference on EU Politics. 25-27 September 2008, Riga, Latvia: University of Latvia.

Waarden, F.V., and M. Drahos. 2002. Courts and (epistemic) communities in the convergence of competition policies. Journal of European Public Policy 9(6): 913-934.

Zito, A.R. 2001. Epistemic communities, collective entrepreneurship and European integration. Journal of European public policy 8(4): 585-603.

Philippe C. Schmitter is the 2009 recipient of the Johan Skytte Prize, the 'Nobel in Political Science' "for his path-breaking work on the role of corporatism in modern democracies, and for his stimulating and innovative analysis of democratization." He was Professor of Political Science at the European University Institute in Florence, Department of Political and Social Sciences until September 2004. He was then nominated Professorial Fellow and later also Professor Emeritus at the same Institution. Previously he was professor in the Politics Department of the University of Chicago (1967-1984), at the European University Institute (1982-1986) and at Stanford (1986-1996). He has published books and articles on comparative politics, on regional integration in Western Europe and Latin America, on the transition from authoritarian rule in Southern Europe and Latin America, and on the intermediation of class, sectoral and professional interests. His current work is on the political characteristics of the emerging Euro-polity, on the consolidation of democracy in Southern and Eastern countries, and on the possibility of post-liberal democracy in Western Europe and North America.

Zoe Lefkofridi is Assistant Professor of Comparative Politics at the University of Salzburg and Joint Jean Monnet-Max Weber Postdoctoral Fellow at the Robert Schuman Centre for Advanced Studies (RSCAS) at the European University Institute in Florence. Her teaching and research focus on European integration, democracy and representation in Europe and beyond, with a focus on political inequalities and extremism. Her work appears in European Political Science Review, European Union Politics, West European Politics and Comparative European Politics, among others. 